\title{
PENGARUH KESIAPAN BELAJAR TERHADAP PRESTASI BELAJAR MAHASISWA PADA PEMBELAJARAN KALKULUS
}

\author{
Triana Harmini \\ Universitas Darussalam Gontor, Jl. Raya Siman KM 6 Kec Siman Ponorogo, \\ triana@unida.gontor.ac.id
}

\begin{abstract}
ABSTRAK
Penelitian ini bertujuan untuk mengetahui ada atau tidaknya hubungan yang signifikan antara kesiapan belajar dengan prestasi belajar mahasiswa pada matakuliah Kalkulus. Penelitian ini dilakukan pada semester ganjil tahun pelajaran 2016/2017. Populasi dalam penelitian ini adalah mahasiswa Program Studi Teknik Informatika Universitas Darussalam Gontor yang menempuh mata kuliah kalkulus yang berjumlah 50 orang. Pengumpulan data dalam penelitian ini menggunakan metode angket dan dokumentasi. Instrumen penelitian yang digunakan adalah angket. Teknik analisis data yang digunakan adalah korelasi Product Moment dan analisis regresi linear sederhana dengan prasyarat analisis yaitu uji normalitas dan linearitas, yang digunakan untuk mengetahui pengaruh kesiapan belajar terhadap prestasi belajar mahasiswa pada mata kuliah Kalkulus. Hasil analisis korelasi Product Moment diperoleh nilai koefisien kesiapan belajar adalah 0.808 dengan nilai signifikansi 0,00 . Hal ini berarti bahwa terdapat korelasi positif dan signifikan antara kesiapan belajar dengan prestasi belajar mahasiswa pada mata kuliah Kalkulus. Sedangkan dari hasil analisis Regresi Linear diperoleh nilai koefisien determinasi sebesar 0,652. Hal ini berarti bahwa kesiapan belajar memberikan pengaruh sebesar $65,8 \%$ terhadap prestasi belajar mahasiswa pada mata kuliah Kalkulus.
\end{abstract}

Kata kunci: Kesiapan, Belajar, Prestasi.

\begin{abstract}
This study aims to determine whether or not a significant relationship between the readiness of learning and students' achievement in Calculus. This study was conducted in the odd semester of the academic year 2016/2017. The population in this study is the students of Informatics Engineering, University of Darussalam Gontor who took calculus course consisting of 50 people. Data collection in this research using questionnaire and documentation method.The research instruments used are questionnaire. Techniques of analysis data used are Product Moment correlation and simple linear regression analysis with prerequisite analyses those are normality and linearity test applied to know the influence of readiness study toward the students' achievement in Calculus course. The analysis result of Product Moment correlation show that the coefficient of readiness is 0.808 with significance score 0,00 . This means that there is a positive and significant correlation between the readiness of learning and the students' achievement in the Calculus course. While the results of Linear Regression analysis shows that determination coefficient is 0.652 . It means that the readiness of study gives an effect of $65,2 \%$ on the students' achievement in Calculus course. Keywords: Readiness, Learning, Achievement.
\end{abstract}

How to Cite: Harmini, T. (2017). Pengaruh Kesiapan Belajar Terhadap Prestasi Belajar Mahasiswa pada Pembelajaran Kalkulus. Mathline: Jurnal Matematika dan Pendidikan Matematika, Vol.2, No.2, 145-158. 


\section{PENDAHULUAN}

Pendidikan merupakan proses yang dapat mengubah obyeknya. Pendidikan bersifat dinamis, melalui pendidikan dapat mempertahankan atau mengembangkan nilai-nilai yang dikehendaki sesuai dengan usaha pengembangan manusia seutuhnya. Melalui pendidikan pula dapat meningkatkan kualitas sumber daya manusia dan mempertebal semangat kebangsaan yang pada akhirnya akan berdampak pada peningkatan pembangunan bangsa. Oleh karena itu perlu dikembangkan iklim belajar dan mengajar yang dapat menumbuhkan rasa percaya diri serta sikap dan perilaku yang inovatif dan kreatif. Pengembangan iklim belajar dan mengajar tersebut pada akhirnya dapat menentukan keberhasilan suatu kegiatan belajar mengajar.

Dalam proses pendidikan yang menjadi pusat atau titik berat adalah peserta didik. Dimana dalam proses pendidikan tersebut akan terjadi proses belajar yang merupakan interaksi antara pengalaman-pengalaman peserta didik dengan materi yang diajarkan. Dalam belajar sangat dibutuhkan persiapan diri untuk menghadapi proses belajar mengajar. Belajar mengakibatkan terjadinya perubahan diri pada orang yang belajar.

Proses belajar mengajar yang terjadi pada lingkungan formal, misalnya sekolah atau perguruan tinggi sangat berpengaruh terhadap perubahan setiap individu, dengan demikian upaya pendidik dalam mewujudkan perubahan tingkah laku peserta didik sangat diperlukan. Pembelajaran bermakna jika peserta didik aktif dalam kegiatan pembelajaran. Keterlibatan peserta ddik secara aktif dapat menciptakan suasana pembelajaran efektif dan saling bekerja sama dalam belajar sehingga tercipta suasana yang menyenangkan.

Kondisi peserta didik yang sehat akan lebih mudah untuk menerima pelajaran dari pendidik. Dengan adanya kesiapan belajar, peserta didik akan termotivasi untuk meningkatkan dan memaksimalkan prestasi belajarnya. Motivasi belajar merupakan salah satu karakteristik yang dapat mempengaruhi aspek afektif. Peserta didik yang memiliki motivasi belajar akan memperhatikan dan berusaha untuk mengingat atas apa yang telah diajarkan. Dengan motivasi yang tinggi peserta didik akan merasa butuh pada materi yang akan dipelajari sehingga akan mempunyai kesiapan belajar yang tinggi pula. Dengan kesiapan belajar yang tinggi akan meningkatkan prestasi belajar.

Belajar adalah karakteristik khusus yang hanya dimiliki oleh manusia. Makhluk lain tidak mampu melakukan proses belajar. Setiap ahli psikologi memberi definisi dan 
batasan yang berbeda-beda tentang makna belajar. Dalam Suyono \& Hariyanto (2011) Hilgard menyatakan bahwa belajar adalah suatu proses dimana suatu perilaku muncul atau berubah karena adanya respon terhadap suatu situasi. Di lain pihak, Gagne (Suyono \& Hariyanto, 2011) menyatakan bahwa belajar adalah sebuah proses perubahan tingkah laku yang meliputi perubahan kecenderungan manusia, seperti sikap, minat, atau nilai dan perubahan kemampuannya, yaitu peningkatan kemampuan untuk melakukan berbagai jenis kinerja. Senada dengan hal tersebut menurut Illeris dan Ormorod belajar adalah suatu proses yang membawa bersama-sama pengaruh dan pengalaman kognitif, emosional, dan lingkungan untuk memperoleh, meningkatkan atau membuat perubahan di dalam pengetahuan, ketrampilan, nilai-nilai dan cara pandang (world views) dari seseorang. Dari pendapat para ahli tersebut disimpulkan bahwa belajar merupakan suatu proses yang berlangsung dalam interaksi aktif yang dapat menghasilkan perubahan dalam pengetahuan, pemahaman, ketrampilan, dan nilai sikap.

Belajar adalah cara seseorang untuk mengetahui suatu perihal yang belum bisa dilakukan. Seseorang baru dapat belajar tentang sesuatu apabila dalam dirinya sudah terdapat kesiapan untuk mempelajari sesuatu itu. Karena dalam kenyataannya setiap individu mempunyai latar belakang perkembangan yang berbeda-beda. Hal ini menyebabkan adanya pola pembentukan kesiapan yang berbeda-beda pula di dalam diri masing-masing individu. Begitu pula kesiapan dalam belajar sangatlah berpengaruh pada perkembangan pribadi seseorang untuk mematangkan kesediaannya dalam belajar, dengan begitu seseorang akan mudah dan siap menerima sesuatu yang akan dipelajari dalam pembelajarannya itu sendiri.

Menurut Slameto (2013) kesiapan belajar adalah keseluruhan kondisi seseorang yang membuatnya siap untuk memberi respon atau jawaban di dalam cara tertentu terhadap suatu situasi. Belajar merupakan suatu usaha untuk memperoleh suatu pemahaman dari apa yang dipelajari. Kesiapan belajar merupakan salah faktor yang dapat mempengaruhi proses belajar.

Nasution (2005), menyatakan bahwa kesiapan belajar adalah kondisi-kondisi yang mendahului kegiatan belajar itu sendiri. Tanpa kesiapan atau kesediaan ini proses belajar tidak akan terjadi. Pra-kondisi belajar ini terdiri atas perhatian, motivasi, dan perkembangan kesiapan. Menurut Nurkancana\& Sumartana (1986) Kesiapan belajar 
dipengaruhi oleh tingkat kematangan siswa. Siswa yang sudah matang, baik secara fisik dan secara psikis, maka siswa tersebut memiliki kesiapan yang lebih baik untuk menerima pelajaran baru dalam proses belajar.

Menurut Djamarah (2002) readiness sebagai kesiapan belajar adalah suatu kondisi seseorang yang telah dipersiapkan untuk melakukan suatu kegiatan. Maksud melakukan suatu kegiatan yaitu kegiatan belajar, misalnya mempersiapkan buku pelajaran sesuai dengan jadwal, mempersiapkan kondisi badan agar siap ketika belajar di kelas dan mempersiapkan perlengkapan belajar yang lainnya. Dari uraian beberapa pakar, maka disimpulkan kesiapan belajar yang dimaksud adalah kondisi seseorang yang telah siap dan mampu untuk menerima dan memberi respon atau rangsangan untuk mendukung tercapainya proses belajar yang baik dan optimal.

Menurut Djamarah (2002) faktor-faktor yang mempengaruhi kesiapan belajar meliputi:

\section{a. Kesiapan fisik}

Kesiapan fisik berkaitan erat dengan kesehatan yang akan berpengaruh pada hasil belajar dan penyesuaian sosial individu. Individu yang kurang sehat mungkin kurangnya vitamin, badanya kurang energi untuk belajar. Hal ini dapat mempengaruhi pada kelancaran proses belajar. Begitupun sebaliknya jika badan tidak sakit (jauh dari gangguan lesu mengantuk, dan sebagainya). Hal ini akan memudahkan untuk belajar karena tidak ada gangguan dari kondisi fisiknya.

b. Kesiapan psikis

Kesiapan psikis berkaitan dengan kecerdasan, daya ingat tinggi, kebutuhan yang terpuaskan, ada hasrat atau motivasi untuk belajar, dapat berkonsentrasi, dan ada perhatian

\section{c. Kesiapan Materiil}

individu dalam mempelajari materi tentunya harus mempunyai bahan yang dapat dipelajari atau dikerjakan, misalnya buku bacaan, buku paket dari sekolah maupun diktat lain yang relevan digunakan sebagai bahan acuan belajar, mempunyai buku catatan dll. Dengan di dukung dengan berbagai sumber bacaan maka akan memberikan pengetahuan dan akan membantu siswa dalam merespon atas pertanyaan-pertanyaan dari guru terkait dengan pelajaran. 
Kesiapan belajar menjadi salah satu faktor yang cukup berpengaruh terhadap prestasi belajar peserta didik. Seorang peserta didik yang telah memiliki kesiapan belajar yang baik sangat besar kemungkinannya untuk mendapatkan hasil belajar yang baik pula. Untuk itulah kesiapan menjadi faktor yang sangat perlu diperhatikan oleh seorang pengajar dalam proses pembelajaran. Menurut Slameto (2013) kesiapan itu perlu diperhatikan dalam proses belajar, karena jika siswa belajar dan padanya sudah ada kesiapan, maka hasil belajarnya akan lebih baik.

Kesiapan belajar mencakup tiga aspek yaitu (1) kondisi fisik, mental dan emosional; (2) kebutuhan, motif, dan tujuan; (3) keterampilan, pengetahuan dan pengertian yang lain yang telah dipelajari. Kondisi fisik adalah kesiapan tubuh jasmani seseorang untuk mengikuti kegiatan belajar. Kondisi mental adalah keadaan yang berhubungan dengan kecerdasan seseorang. Kondisi emosional adalah kondisi seseorang untuk dapat mengatur emosinya dalam mengahadapi masalah. Kebutuhan merupakan segala sesuatu yang harus dipenuhi pada saat itu juga atau rasa membutuhkan terhadap materi yang dipelajari. Rasa membutuhkan mendorong seseorang untuk siap berbuat sesuatu. Sehingga kebutuhan sangat erat hubungannya dengan kesiapan belajar.

Kesiapan belajar timbul dari dalam diri seseorang yang berhubungan dengan kematangan, karena kematangan berarti kesiapan untuk melakukan sesuatu. Oleh karena itu prestasi belajar akan baik jika dilakukan bersamaan dengan tingkat kematangan individu. Kesiapan belajar erat hubungannya dengan minat dan kebutuhan anak dalam belajar.

Slameto (2013) menjelaskan bahwa ada dua faktor yang mempengaruhi keberhasilan siswa dalam belajar, yaitu faktor intern dan faktor ekstern. Faktor intern merupakan faktor yang berasal dari dalam individu yang dibagi menjadi tiga macam yakni faktor jasminiah (meliputi faktor kesehatan dan faktor cacat tubuh), faktor psikologis (meliputi intelegensi, perhatian, minat, bakat, motif, kematangan serta kesiapan) serta faktor kelelahan baik secara jasmani maupun rohani. Sedangkan faktor ekstern merupakan faktor yang berasal dari luar diri siswa yang meliputi faktor keluarga, faktor sekolah dan faktor masyarakat. 
Unsur-unsur belajar merupakan faktor-faktor yang menjadi indikator keberhasilan proses belajar. Cronbach dalam Suyono \& Hariyanto (2011) menyatakan tujuh unsur dalam proses belajar, yang meliputi:

1. tujuan, tujuan muncul karena adanya sesuatu kebutuhan;

2. kesiapan, agar mampu melaksanakan proses belajar dengan baik, anak perlu memiliki kesiapan baik kesiapan fisik, psikis, maupuan kesiapan yang berupa kematangan untuk melakukan sesuatu yang terkait dengan pengalaman belajar;

3. situasi, kegiatan belajar berlangsung dalam situasi belajar;

4. interpensi, interpensi dilakukan dengan melihat hubungan di antara komponenkomponen situasi belajar, melihat makna dari hubungan tersebut dan mengghubungkannya dengan kemungkinan pencapaian tujuan;

5. respon, respon dapat berupa usaha yang terencana dan sistematis ataupun usaha cobacoba;

6. konsekuensi, berupa hasil baik hasil positif maupun negatif sebagai konsekuensi respon yang dipilih siswa;

7. reaksi terhadap kegagalan, kegagalan dapat menurunkan semangat. Motivasi, memperkecil usaha-usaha belajar selanjutnya. Namun. Dapat juga membangkitkan siswa karena dia mau belajar dari kegagalan.

Kesiapan belajar dapat mempengaruhi proses belajar mengajar. Jika proses belajar mengajar terganggung, maka akan berpengaruh pula pada prestasi belajar. Menurut Tirtonegoro (1984) prestasi adalah penilaian hasil kegiatan belajar mengajar yang dinyatakan dalam bentuk symbol,angka, huruf maupun hal yang dapat mencerminkan hasil yang dicapai oleh anak dalam periode tertentu. Menurut Arifin (1990) prestasi adalah hasil yang telah dicapai (dari yang telah dilakukan, dikerjakan, dan sebagainya). Winkel (1996) mengemukakan bahwa prestasi adalah bukti usaha yang telah dicapai. Di dalam pengertian tersebut, prestasi merupakan suatu usaha yang telah dilaksanakan menurut batas kemampuan dari pelaksanaan proses pendidikan dan latihan tertentu.Berdasarkan beberapa pendapat di atas dapat ditarik kesimpulan bahwa prestasi adalah hasil yang dicapai seseorang setelah melaksanakan suatu usaha dinyatakan dalam bentuk simbol, angka, huruf maupun hal yang dapat mencerminkan hasil yang sudah dicapai oleh setiap anak pada periode tertentu. 
Menurut Mulyani (2013) siswa yang tidak memiliki kesiapan belajar cenderung mendapatkan prestasi belajar yang rendah. Sebaliknya siswa yang memiliki kesiapan belajar dengan baik memiliki prestasi belajar yang baik pula. Sehingga dapat diketahui bahwa tinggi rendahnya hasil prestasi siswa dapat dilihat dari kesiapan belajar yang dimiliki selama proses pembelajaran. Rahmawati (2015) melakukan penelitian terkait hubungan kesiapan belajar dan kepercayaan diri dengan prestasi belajar an diperoleh kesimpulan bahwa terdapat hubungan yang positif dan signifikan antara kesiapan belajar dan kepercayaan diri terhadap prestasi belajar matematika baik secara sendiri-sendiri maupun secara bersama-sama.

Berdasarkan pengamatan yang dilakukan peneliti, kesiapan belajar mahasiswa Program Studi Teknik Informatika UNIDA Gontor masih cenderung rendah. Hal ini ditunjukkan dengan kondisi mahasiswa saat proses pembelajaran. Saat proses pembelajaran berlangsung, ditemukan berbagai macam kondisi yang dapat menghambat kesiapan belajar mahasiswa. Beberapa hambatan tersebut antara lain, kurangnya keinginan mahasiswa untuk berprestasi, adanya sebagian mahasiswa yang kurang memperhatikan penjelasan dari dosen saat proses pembelajaran berlang sung, sebagian mahasiswa yang memiliki tingkat kemampuan memahami materi yang diberikan lemah, dan ada juga mahasiswa yang datang tidak tepat waktu pada jam perkuliahan.

Berdasarkan latar belakang yang telah diuraikan di atas, maka permasalah dalam penelitian ini adalah apakah terdapat hubungan positif yang signifikan antara kesiapan belajar dengan prestasi belajar mahasiswa pada mata kuliah Kalkulus. Tujuan dalam penelitian ini adalah untuk mengetahui ada atau tidaknya hubungan positif yang signifikan antara kesiapan belajar dengan pretasi belajar mahasiswa pada matakuliah Kalkulus.

\section{METODE PENELITIAN}

Penelitian ini bertujuan untuk mengetahui ada atau tidaknya hubungan yang signifikan antara kesiapan belajar dengan prestasi belajar mahasiswa pada matakuliah Kalkulus.Pendekatan yang digunakan adalah pendekatan kuantitatif. Penelitian ini menggunakan jenis rancangan penelitian non eksperimen dengan desain penelitian korelasional, yang mana akan melihat hubungan antara variabel atau beberapa variabel 
dengan variabel yang lain. Dalan penelitian ini menggunkan metode analasis korelasi Pearson atau Product Moment.

Penelitian ini dilakukan pada semester ganjil tahun pelajaran 2016/2017. Populasi dalam penelitian ini adalah seluruh mahasiswa Program Studi Teknik Informatika Universitas Darussalam Gontor yang mengambil mata kuliah Kalkulus yang berjumlah 50 mahasiswa yang terdiri dari 2 kelas yaitu kelas A yang berjumlah 28 mahasiswa dan kelas B yang berjumlah 22 mahasiswa. Dikarenakan banyak populasi dalam penelitian ini kurang dari 100 maka dalam penelitian semua populasi penelitian digunakan sebagai subjek penelitian sehingga penelitian ini merupakan penelitian populasi.

Metode pengumpulan data yang digunakan adalah metode angket (kuesioner) dan dokumentasi. Metode angket digunakan untuk mengumpulkan data kesiapan belajar. Instrumen yang digunakan adalah angket kesiapan belajar untuk mengukur tingkat kesiapan belajar mahasiswa. Metode dokumentasi digunakan untuk mengumpulkan data prestasi belajar. Data prestasi belajaryang digunakan diperoleh dari dokumen nilai ujian akhir semester pada mata kuliah Kalkulus.

Teknik analisis data menggunakan korelasi Pearson (Product Moment) dan analisis regresi linear sederhana dengan prasyarat analisis yaitu uji normalitas dan uji linearitas. Untuk mempermudah penghitungan dan analisis pada penelitian ini dilakukan dengan bantuan komputer melalui programIBM SPSS Statistic 22.Dalam penelitian ini terdapat satu variabel bebas dan satu variabel terikat, yaitu kesiapan belajar sebagai variabel bebas (variebal X) dan prestasi belajar sebagai variabel terikat (variabel Y).

Langkah-langkah analisis data dalam penelitian ini, sebagai berikut:

1. Uji normalitas digunakan untuk mengetahui apakah data berdistribusi normal atau tidak. Pada penelitian ini menggunakan uji Kolmogorov-Smirnov dengan menggunakan taraf signifikansi $5 \%$ atau 0,05 , dengan syarat pengambilan keputusan sebagai berikut:

a) Jika nilai probabilitas ( $\mathrm{Sig}) \geq 0,05$ maka distribusinya adalah normal

b) Jika nilai probabilitas ( $\mathrm{Sig})<0,05$ maka distribusinya adalah tidak normal

2. Uji linearitas bertujuan untuk mengetahui apakah dua variabel mempunyai hubungan yang linear atau tidak secara signifikan. Uji ini digunakan sebagai prasyarat dalam analisis korelasi atau regresi linear.Pengujian pada SPSS dengan menggunakan Test for 
Linearity dengan pada taraf signifikansi 0,05, dengan syarat pengambilan kesimpulan sebagai berikut:

a) Jika nilai probabilitas (Sig) dari nilai Linearity $\geq 0,05$ maka dua variabel mempunyai hubungan yang tidak linear.

b) Jika nilai probabilitas (Sig) dari nilai Linearity< 0,05 maka dua variabel mempunyai hubungan yang linear.

3. Analisis korelasi sederhana digunakan untuk menentukan arah dan kuat lemahnya hubungan antar variabel yaitu variabel kesiapan belajar dan variabel prestasi belajar. Analisis korelasi yang digunakan adalah korelasi Pearson atau Product Moment, dengan rumus:

$$
r_{x y}=\frac{n \sum X Y-\left(\sum X\right)\left(\sum Y\right)}{\sqrt{\left(n \sum X^{2}-\left(\sum X\right)^{2}\right)\left(n \sum Y^{2}-\left(\sum Y\right)^{2}\right)}}
$$

Nilai $r_{x y}$ merupakan koefisien korelasi. Koefisien korelasi merupakan sebuah bilangan yang menunjukkan tingkat kedekatan hubungan antara dua variabel, dan menggambarkan sejauh mana variansis pada satu variabel berdampak atas variansis variabel yang lain (Reksoatmodjo, 2009). Arah hubungan dua variabel ditentukan dari tanda positif atau negatif koefisien korelasi. Jika koefisien korelasi bertanda positif menunjukkan arah hubungan antara variabel $\mathrm{X}$ dan $\mathrm{Y}$ yang searah artinya semakin besar nilai variabel $\mathrm{X}$ semakin besar juga nilai variabel $\mathrm{Y}$, dan sebaliknya. Jika koefisien korelasi bertanda negatif menunjukkan arah hubungan atara $\mathrm{X}$ dan $\mathrm{Y}$ yang terbalik, artinya semakin besar nilai variabel $\mathrm{X}$ semakin kecil nilai variabel $\mathrm{Y}$, dan sebaliknya.Untuk memudahkan melakukan interpretasi mengenai kekuatan hubungan antara dua variabel, Quadratullah (2014) menyebutkan tingkat hubungan dua variabel menjadi lima tingkat, yaitu sempurna, sangat kuat, kuat, lemah, sangat lemah, dan tidak ada. Tingkat hubungan dua variabel ditunjukkan dalam tabel 1 .

Tabel 1. Tingkat Hubungan Dua Variabel

\begin{tabular}{cc}
\hline Koefisien Korelasi $\left(\boldsymbol{r}_{x y}\right)$ & Tingkat Hubungan \\
\hline$r_{x y}=1$ & Sempurna \\
$0.75 \leq r_{x y}<1$ & Sangat Kuat \\
$0.5 \leq r_{x y}<0.75$ & Kuat \\
$0.25 \leq r_{x y}<0.5$ & Lemah \\
$0<r_{x y}<0.25$ & Sangat Lemah \\
$r_{x y}=0$ & Tidak Ada \\
\hline
\end{tabular}

4. Uji hipotesis untuk mengetahui apakah koefisien korelasi yang diperoleh signifikan 
atau tidak. Signifikansi koefisien korelasi ditentukan dengan melihat nilai probabilitas (sig-2 talied). Jika nilai Sig-2tailed $\geq 0.05$ maka disimpulkan bahwa koefisien korelasi tidak signifikan, artinya koefisien korelasi tidak cukup mewakili keseluruhan data. Jika nilai Sig-2tailed $<0.05$ maka disimpulkan bahwa koefisien korelasi signifikan dapat meakili keseluruhan data.

Analisis regresi dapatdigunakan untuk mengetahui seberapa besar pengaruh variabel bebas terhadap variabel terikat. Besar pengaruh dinyatakan dalam bentuk koefisien determinasi. Nilai koefisien determasi dapat dipakai untuk memprediksi seberapa besar kontribusi pengaruh variabel bebas $(\mathrm{X})$ terhadap variabel terikat $(\mathrm{Y})$ dengan syarat hasil uji $\mathrm{F}$ dalam analisis regresi bernilai signifikan. Sebaliknya jika hasil uji F tidak signifikan maka nilai koefisien determinasi tidak dapat digunakan untuk memprediksi kontribusi pengaruh variabel X terhadap variabel Y. Signifikansi uji F ditentukan dari nilai probablitas (sig) pada analisis regresi. Jika nilai Sig kurang dari 0.05 maka disimpulkan bahwa uji F signifikan, dan sebaliknya jika nilai Sig lebih dari atau sama dengan 0.05 maka disimpulkan bahwa uji F tidak signifikan.

\section{HASIL DAN PEMBAHASAN}

Dalam penelitian ini terdapat dua jenis data, yaitu data kesiapan belajar dan data prestasi belajar. Data kesiapan belajar diperoleh dari hasil angket kesiapan belajar, sedangkan data prestasi belajar diperoleh dari hasil nilai ujian akhir semester pada mata kuliah Kalkulus. Selanjutnya, dari kedua data dianalisis untuk mengetahui hubungan antara kesiapan belajar dengan prestasi belajar mahasiswa pada mata kuliah Kalkulus.

Teknik analisis data dilakukan dengan pengujian prasyarat dan pengujian hipotesis. Uji prasyarat analisis yang dilakukan adalah uji normalitas dan uji linearitas. Uji normalitas digunakan untuk mengetahui apakah sebaran data yang diperoleh berdistribusi normal atau tidak. Uji normalitas dilakukan pada data prestasi belajar mahasiswa. Ringkasan hasil uji normalitas data prestasi belajar mahasiswa disajikan dalam tabel 2.

Tabel 2. Hasil Uji Normalitas Data Prestasi Belajar

\begin{tabular}{lccccccr}
\hline & \multicolumn{3}{c}{ Kolmogorov-Smirnov } & \multicolumn{4}{c}{ Shapiro-Wilk } \\
\cline { 2 - 9 } prestasi & Statistic & df & Sig. & Statistic & df & \multicolumn{1}{c}{ Sig. } \\
\cline { 2 - 8 } & .083 & 50 & $.200^{*}$ & .954 & 50 & .048 \\
\hline
\end{tabular}

*. This is a lower bound of the true significance.

a. Lilliefors Significance Correction 
Berdasarkan tabel 2 dapat diketahui bahwa nilai probabilitas (Sig) dari uji Kolmogorov-Smirnov untuk dara prestasi belajar yaitu 0,200. Nilai probabilitas lebih besar dari 0,05 sehingga dapat disimpulkan bahwa data prestasi belajar berdistribusi normal.

Uji linearitas digunakan untuk mengetahui apakah hubungan antara kesiapan belajar dan prestasi belajar mahasiswa memiliki hubungan yang linear atau non-linear. Uji linearitas digunakan Test of Linearity pada menu Mean di dalam IBM SPSS Statistic 22. Ringkasan hasil uji linearitas disajikan dalam tabel 3.

Tabel 3. Hasil Uji linearitas Data Kesiapan Belajar dan Prestasi Belajar

\begin{tabular}{lllrrrrr}
\hline & & & \multicolumn{1}{c}{$\begin{array}{c}\text { Sum of } \\
\text { Squares }\end{array}$} & \multicolumn{1}{c}{ df } & \multicolumn{1}{c}{ Mean } \\
Square & \multicolumn{1}{c}{ F } & \multicolumn{1}{c}{ Sig. } \\
\hline $\begin{array}{l}\text { kesiapan * } \\
\text { prestasi }\end{array}$ & Between & (Combined) & 7130.925 & 18 & 396.162 & 8.283 & .000 \\
& & $\begin{array}{l}\text { Linearity } \\
\text { Deviation } \\
\text { from }\end{array}$ & 5616.797 & 1 & 5616.797 & 117.443 & .000 \\
& & 1514.128 & 17 & 89.066 & 1.862 & .065 \\
& Linearity & & & & & \\
& Within Groups & & 1482.595 & 31 & 47.826 & & \\
\hline
\end{tabular}

Berdasarkan tabel 3 dapat diketahui bahwa nilai probabilitas (Sig) untuk linearity yaitu 0,000 kurang dari 0,05 sehingga dapat disimpulkan bahwa kedua variabel mempunyai hubungan yang linear. Karena data berdistribusi normal dan kedua variabel mempunyai hubungan yang linear, maka pengujian hipotesis dilakukan dengan uji statistik parametrik yaitu dengan menggunakan uji korelasi Pearson. Ringkasan hasil analisis korelasi disajikan dalam tabel 4.

Tabel 4. Hasil Analisis Korelasi Pearson

\begin{tabular}{rlrr}
\hline & Kesiapan & Prestasi \\
\hline kesiapan & Pearson Correlation & 1 & $.808^{* *}$ \\
& Sig. (2-tailed) & & .000 \\
& $\mathrm{~N}$ & 50 & 50 \\
\multirow{3}{*}{ Prestasi } & Pearson Correlation & $.808^{* *}$ & 1 \\
& Sig. (2-tailed) & .000 & 50 \\
& $\mathrm{~N}$ & 50 & \\
& & & \\
\end{tabular}

**. Correlation is significant at the 0.01 level (2-tailed).

Dari hasil perhitungan yang dilakukan dengan korelasi Pearson diperoleh harga koefisien korelasi sebesar 0.808. Koefisien korelasi menunjukkan nilai positif, yang berarti bahwa terdapat hubungan yang searah antara kesiapan belajar dengan prestasi belajar mahasiswa. Nilai koefisien korelasi menunjukkan angka 0.808 yang dapat dikategorikan bahwa hubungan antara kedua variabel sangat kuat. Untuk menguji apakah koefisien korelasi yang diperoleh signifikan atau tidak, dapat dilihat dari nilai probabilitas (Sig). Nilai 
sig (2-tailed) adalah 0.000 kurang dari 0.05 yang mengandung pengertian bahwa terdapat hubungan yang signifikan antara kesiapan belajar dan prestasi belajar.

Untuk melihat besar kontribusi pengaruh kesiapan belajar terhadap prestasi belajar mahasiswa, maka perlu ditentukan nilai koefisien determinasi. Nilai koefisien determinasi diperoleh dari hasil analisis regresi linear sederhana. Hasil analisis regresi linear sederhana disajikan dalam tabel 5.

Tabel 5. Hasil Analisis Regresi

\begin{tabular}{|c|c|c|c|c|c|c|c|c|c|}
\hline \multirow[b]{2}{*}{ Model } & \multirow[b]{2}{*}{$\mathbf{R}$} & \multirow[b]{2}{*}{$\begin{array}{c}\mathbf{R} \\
\text { Square }\end{array}$} & \multirow[b]{2}{*}{$\begin{array}{l}\text { Adjusted } \\
\text { R Square }\end{array}$} & \multirow{2}{*}{$\begin{array}{l}\text { Std. Error } \\
\text { of the } \\
\text { Estimate }\end{array}$} & \multicolumn{5}{|c|}{ Change Statistics } \\
\hline & & & & & $\begin{array}{c}\text { R Square } \\
\text { Change }\end{array}$ & $\begin{array}{c}\text { F } \\
\text { Change }\end{array}$ & df1 & df2 & $\begin{array}{c}\text { Sig. F } \\
\text { Change }\end{array}$ \\
\hline 1 & $.808^{a}$ & .652 & .645 & 3.778 & .652 & 89.967 & 1 & 48 & .000 \\
\hline
\end{tabular}

Dari analisis regresi diperoleh nilai $\mathrm{R}$ square sebesar 0,652 . Nilai $\mathrm{R}$ square merupakan nilai dari koefisien determinasi, yang dalam hal ini berarti bahwa 65,2\% dari prestasi belajar mahasiswa dipengaruhi oleh kesiapan belajar. Sedangkan sisanya yaitu sebesar $34,8 \%$ dipengaruhi oleh faktor yang lain. Hal ini menunjukkan bahwa kesiapan belajar memberikan pengaruh yang cukup besar terhadap prestasi belajar. Nilai Sig F Change menunjukkan nilai signifikansi dari uji F. Pada tabel 4 nilai Sig uji F menunjukkan angka 0.000 kurang dari 0.05 . Hal ini berarti bahwa uji $\mathrm{F}$ signifikan yang dapat diartikan bahwa koefisien determinasi dapat digunakan untuk memprediksi seberapa besar kontribusi pengaruh variabel kesiapan belajar terhadap variabel prestasi belajar mahasiswa.

Astuti, dkk (2016) melakukan penelitian mengenai pengaruh readiness, selfconfidence, serta readiness dan self-confidence secara bersama-sama terhadap penguasaan mahasiswa pada mata kuliah Geometri Transformasi. Hasil penelitian ini menunjukkan bahwa terdapat pengaruh yang positif dan signifikan antara readiness, self-confidence, serta readiness dan self-confidence secara bersama-sama terhadap penguasaan mahasiswa pada mata kuliah Geometri Transformasi. Hasil yang diperoleh senada dengan hasil dalam penelitian ini.

Slameto (2013) menyatakan bahwa kesiapan belajar merupakan salah satu aspek yang mempengaruhi hasil belajar siswa. Hal ini sesuai dengan hasil dalam penelitian ini yang menunjukkan bahwa kesiapan belajar memberikan kontribusi pengaruh yang cukup 
besar terhadap prestasi belajar mahasiswa. Kondisi mahasiswa yang memiliki kesiapan belajar akan memberikan respon aktif selama pembelajaran. Kesiapan belajar dapat dilihat dari kemauannya untuk melakukan sesuatu atas dasar kemauan dan kesediaan dirinya sendiri tanpa ada paksaan dan perintah orang lain. Kesiapan belajar akan membuat siswa mudah menyesuaikan dengan kondisi apapun. Belajar adalah kondisi dimana siswa mengalami dan menjalani yang sebelumnya didahului oleh suatu situasi. Tanpa kesiapan dan kesediaan belajar maka proses belajar tidak akan terjadi. Kesiapan belajar merupakan salah satu faktor yang mempengaruhi proses belajar. Terpengaruhinya proses belajar akan berpengaruh juga terhadap prestasi belajarnya.

\section{KESIMPULAN}

Dari keseluruhan penelitian yang dilakukan dapat disimpulkan bahwa terdapat hubungan yang kuat dan positif antara kesiapan belajar dan prestasi belajar mahasiswa pada mata kuliah Kalkulus. Kesiapan belajar memberikan pengaruh yang cukup besar terhadap prestasi belajar disamping faktor-faktor lain di luar kesiapan belajar.

Dari hasil penelitian ini, maka disarankan kepada guru maupun dosen untuk memperhatikan kesiapan belajar mahasiswa sebelum memulai proses pembelajaran, karena kesiapanbelajar mahasiswa akan mempengaruhi kegiatan belajar siswa dan tentunya akan berpengaruh terhadap prestasi belajar. Bagi para siswa, hendaknya melakukan kesiapan belajar sebaik-baiknya sebelum memulai kegiatan belajar agar apa yang dipelajari dapat dipahami dengan baik dan diharapkan akan baik juga prestasi belajarnya.

\section{UCAPAN TERIMA KASIH}

Ucapan terima kasih disampaikan kepada Fakultas Sains dan Teknologi prodi Teknik Informatika yang telah membantu terselesaikannya penelitian ini. Terima kasih juga disampaikan kepada Prodi Pendidikan Matematika Universitas Wiraloda yang telah menerima dan menerbitkan artikel ini pada jurnal Mathline Volume 2 Nomer 2 Tahun 2017.

\section{DAFTAR PUSTAKA}

Arifin, Z. (1990). Evaluasi Instruksional. Bandung: Remaja Karya.

Astuti, E. P, Kurniasih, N., \& Nugraheni, P. (2016). Hubungan Readiness dan Self- 
Confidence Terhadap Penguasaan Geometri Transformasi Mahasiswa Pendidikan Matematika Universitas Muhammadiyah Purworejo. Beta Jurnal Tadris Matematika 9(1), 78-88.

Djamarah, S. B. (2002). Rahasia Sukses Belajar. Jakarta: Rineka Cipta

Mulyani, D. (2013). Hubungan Kesiapan Belajar Siswa dengan Prestasi Belajar. Jurnal Ilmiah Konseling. Vol. 2 (1), 27-31.

Nasution, S. (2005). Berbagai Pendekatan dalam Proses Belajar \& Menagajar. Jakarta: Bumi Aksara.

Nurkancana, W \& Sumartana. (1986). Evaluasi Pendidikan. Surabaya: Usaha Nasional.

Quadratullah, M.F. (2014). Statistika Terapan: Teori, Contoh Kasus, dan Aplikasi dengan SPSS. Yogyakarta: ANDI OFFSET.

Rahmawati, R. N. (2015). Pengaruh Kesiapan Belajar Dan Kepercayaan Diri Terhadap Prestasi Belajar Matematika. Jurnal Ekuivalen: Universitas Muhammadiyah Purworejo. Vol 18 (1), 45-50.

Reksoatmodjo, T. N. (2009). Statistika Teknik. Bandung: Refika Aditama.

Slameto. (2013). Belajar dan Faktor-faktor yang Mempengaruhinya. Jakarta: Rineka Cipta.

Suyono \& Hariyanto. (2011). Belajar dan Pembelajaran. Bandung: Remaja Rosdakarya.

Tirtonegoro, S. (1984). Psikologi Pendidikan. Jakarta: Rajawali.

Winkel, W. S. (1996). Psikologi Pengajaran. Jakarta: PT. Gramedia Widiasarana Indonesia.. 